\title{
Modification of Aniline Containing Proteins Using an Oxidative Coupling Strategy
}

\author{
Jacob M. Hooker, Aaron P. Esser-Kahn, and Matthew B. Francis* \\ Department of Chemistry, University of California, Berkeley, CA 94720-1460, and Material Science Division, Lawrence Berkeley National Labs, Berkeley, CA $94720-1460$
}

\section{Supporting Information}

\section{$\underline{\text { General Procedures and Materials }}$}

Unless otherwise noted, all chemicals were obtained from commercial sources and used without further purification. Analytical thin layer chromatography (TLC) was performed on EM Reagent $0.25 \mathrm{~mm}$ silica Gel $60-\mathrm{F}_{254}$ plates with visualization by ultraviolet (UV) irradiation at $254 \mathrm{~nm}$, vanillin or potassium permanganate stain. Purifications by flash chromatography were performed using EM silica gel 60 (230-400 mesh). The eluting system for each purification was determined by TLC analysis. Chromatography solvents were used without distillation. All reactions were carried out under an argon atmosphere in oven dried glassware unless otherwise noted. All organic solvents were removed under reduced pressure using a rotary evaporator. Dichloromethane $\left(\mathrm{CH}_{2} \mathrm{Cl}_{2}\right)$ and acetonitrile $(\mathrm{MeCN})$ were distilled under a nitrogen atmosphere from calcium hydride. Water $\left(\mathrm{ddH}_{2} \mathrm{O}\right)$ used in biological procedures or as a reaction solvent was deionized using a NANOpure ${ }^{\mathrm{TM}}$ purification system (Barnstead, USA). Lysozyme was purchased from Sigma and used without further purification. Bovine $\alpha$-Chymotrypsinogen A was purchased from MP Biomedicals, Inc. and used without further purification.

\section{Instrumentation and Sample Analysis Preparations}

NMR. ${ }^{1} \mathrm{H}$ and ${ }^{13} \mathrm{C}$ spectra were measured with a Bruker DRX-500 (500 MHz) spectrometer, a Bruker AVB-400 (400 MHz) spectrometer, or a Bruker AV-500 (500 MHz) as noted. ${ }^{1} \mathrm{H}$ NMR chemical shifts are reported as $\delta$ in units of parts per million (ppm) relative to chloroform- $d\left(\delta 7.26\right.$, singlet), methanol- $d_{4}\left(\delta 3.31\right.$, pentet), dimethyl sulfoxide- $d_{6}\left(\delta 2.50\right.$, pentet), or acetonitrile- $d_{3}$ ( $\delta 1.94$, pentet). Multiplicities are reported as follows: s (singlet), d (doublet), t (triplet), q (quartet), dd (doublet of doublets), dt (doublet of triplets), ddd (doublet of doublet of doublets) or m (multiplet). Coupling constants are reported as a $J$ value in Hertz (Hz). The number of protons ( $\mathrm{n}$ ) for a given resonance is indicated as $\mathrm{nH}$, and is based on spectral integration values. ${ }^{13} \mathrm{C}$ NMR chemical shifts are reported as $\delta$ in units of parts per million ( $\mathrm{ppm})$ relative to chloroform- $d\left(\delta 77.1\right.$, triplet), methanol- $d_{4}\left(\delta 49.0\right.$, septet), dimethyl sulfoxide- $d_{6}(\delta 39.5$, septet), or acetonitrile- $d_{3}(\delta 1.3$, singlet; 118.3 septet $)$.

Mass Spectrometry. Fast Atom Bombardment (FAB) and Electron Impact (EI) mass spectra were obtained at the UC Berkeley Mass Spectrometry Facility. Matrix assisted laser desorption-ionization time-of-flight mass spectrometry (MALDI-TOF MS) was performed on a Voyager-DE ${ }^{\mathrm{TM}}$ system (PerSeptive Biosystems, USA). All samples were co-crystallized using a sinapinic acid solution (10 $\mathrm{mg} / \mathrm{mL}$ in $7: 3 \mathrm{MeCN}: \mathrm{ddH}_{2} \mathrm{O}$ with $0.1 \%$ TFA). Electrospray LC/MS analysis was performed using an API 150EX system (Applied Biosystems, USA) equipped with a Turbospray source and an Agilent 1100 series LC pump. Protein chromatography was performed using a Phenomenex Jupiter C5 reversed phase column (2.0 mm x $150 \mathrm{~mm})$ with a MeCN: $\mathrm{ddH}_{2} \mathrm{O}$ gradient mobile phase containing $0.1 \%$ formic acid $(250 \mu \mathrm{L} / \mathrm{min})$. Protein mass reconstruction was performed on the charge ladder with Analyst software (version 1.3.1, Applied Biosystems). Prior to MS analysis, biological samples were desalted and/or separated from small molecule contaminants using $\mu \mathrm{C} 18$ ZipTip ${ }^{\circledR}$ pipet tips (Millipore, USA), NAP- $5^{\mathrm{TM}}$ gel filtration columns (Amersham Biosciences, USA), or Strata C-18E ${ }^{\mathrm{TM}}$ reversed-phase columns (Phenomenex, USA) as indicated below. All MS data for protein and peptide samples were found to be within $0.1 \%$ of the expected values. 
High Perfomance Liquid Chromatography. HPLC was performed on an Agilent 1100 Series HPLC System (Agilent Technologies, USA). Sample analysis for all HPLC experiments was achieved with an in-line diode array detector (DAD) and an in-line fluorescence detector (FLD).

Gel Analyses. For protein analysis, sodium dodecyl sulfate-polyacrylamide gel electrophoresis (SDS-PAGE) was accomplished on a Mini-Protean apparatus (Bio-Rad, USA). Commercially available markers (Bio-Rad, USA) were applied to at least one lane of each gel for calculation of apparent molecular weights. Visualization of protein bands was accomplished by staining with Coomassie ${ }^{\circledR}$ Brilliant Blue R-250 (Bio-Rad, USA). For fluorescent protein conjugates, the bromophenol blue gel running front was excised to avoid non-specific dye staining. Subsequent visualization was accomplished on a UV backlight (306 nm). Gel imaging was performed on an EpiChem3 Darkroom system (UVP, USA).

\section{Experimental \& Supporting Data}

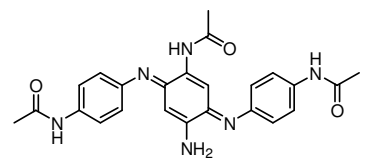

$N$-\{4-[5-Acetylamino-4-[4-acetylamino-phenylimino]-2-amino-cyclohexa-2,5-dienylideneamino]phenyl\}-acetamide (2). To $45 \mathrm{~mL}$ of water was added $5 \mathrm{~mL}$ of a solution of $N$-(4-aminophenyl)acetamide

$(100 \mathrm{mM}$ in $\mathrm{MeCN})$. The resulting stirred solution was treated in one portion with $10 \mathrm{~mL}$ of an aqueous solution of sodium periodate $(250 \mathrm{mM}, 5$ eqv). Upon addition of the oxidant, an immediate orange/red color was observed followed immediately by an orange/brown precipitate. After $5 \mathrm{~min}$, the precipitate was isolated by centrifugation and then washed three times by repetitions of suspension in $25 \mathrm{~mL}$ of water followed by centrifugation. The solid was dissolved in a small volume of 1:1 MeOH:EtOAc, dried over $\mathrm{Na}_{2} \mathrm{SO}_{4}$ and purified by flash chromatography (EtOAc:MeOH) to afford $70 \mathrm{mg}$ of 2 (94\% yield). ${ }^{1} \mathrm{H}$ NMR (400 MHz, DMSO- $\left.d_{6}\right): \delta, 2.06$ (s, 3H), 2.07 (s, 3H), $2.10(\mathrm{~s}, 1 \mathrm{H}), 5.70$ (s, $1 \mathrm{H}), 6.38(\mathrm{~s}, 2 \mathrm{H}), 6.84$ (m (2 overlapping doublets), 4H), 7.59-7.65 (m (2 overlapping doublets), 4H), $9.45(\mathrm{~s}, 1 \mathrm{H}), 9.94(\mathrm{~s}, 1 \mathrm{H}), 10.00(\mathrm{~s}, 1 \mathrm{H})$. ${ }^{13} \mathrm{C}$ NMR (100 MHz, DMSO- $\left.d_{6}\right): \delta, 24.4,25.0,25.1,91.0,99.2,119.9$, $120.1,121.5,121.8,134.6,136.0,136.8,145.2$, 145.9, 148.5, 153.7, 154.6, 168.5, 168.6, 169.7. LRMS (ESI) calculated for $\mathrm{C}_{24} \mathrm{H}_{24} \mathrm{~N}_{6} \mathrm{O}_{3}$

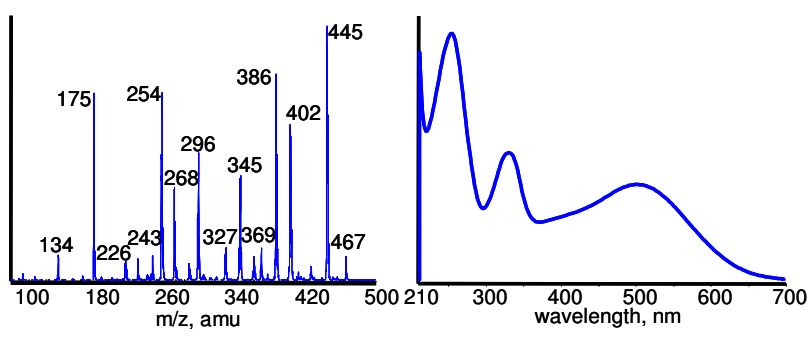

Figure S1. Spectral characteristics of 2. (left) ESI-MS, (right) UV-Vis. $\left([\mathrm{M}+\mathrm{H}]^{+}\right) 445$, found 445 .

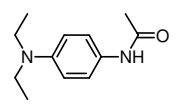

$N$-(4-Diethylamino-phenyl)-acetamide (3). $N, N$-diethyl- $p$-phenylenediamine $(1.0 \mathrm{~mL}, 6.1 \mathrm{mmol})$ was added dropwise to a stirred solution of acetic anhydride $(2 \mathrm{~mL}, 18.1 \mathrm{mmol})$ in pyridine $(5 \mathrm{~mL})$ at $0{ }^{\circ} \mathrm{C}$. The resulting solution was stirred for 5 min at $0{ }^{\circ} \mathrm{C}$ and then allowed to warm to rt. After $30 \mathrm{~min}$, the solution was partitioned between EtOAc $(50 \mathrm{~mL})$ and water $(150 \mathrm{~mL})$. The organic layer was washed with water $(2 \times 100 \mathrm{~mL})$ followed by brine $(50 \mathrm{~mL})$ and then concentrated under reduced pressure. Purification by flash chromatography (EtOAc:Hexanes) afforded $0.94 \mathrm{~g}$ of $\mathbf{3}$ as a gray/green solid (75\% yield): ${ }^{1} \mathrm{H} \mathrm{NMR}\left(400 \mathrm{MHz}^{\mathrm{CDCl}} 3\right): \delta, 1.15$ (t, $6 \mathrm{H}, J=7.2 \mathrm{~Hz}), 2.13(\mathrm{~s}, 3 \mathrm{H}), 3.36(\mathrm{q}, 4 \mathrm{H}, J=7.2 \mathrm{~Hz}), 6.62(\mathrm{~d}, 2 \mathrm{H}, J=8.8 \mathrm{~Hz}), 7.16(\mathrm{br} \mathrm{s}, 1 \mathrm{H}), 7.28(\mathrm{~d}, 2 \mathrm{H}, J=8.8 \mathrm{~Hz}) .{ }^{13} \mathrm{C} \mathrm{NMR}(100$ $\mathrm{MHz}, \mathrm{CDCl}_{3}$ ): $\delta, 12.5,24.2,44.5,111.7,112.3,122.5,128.0,168.2$. HRMS (FAB) calculated for $\mathrm{C}_{12} \mathrm{H}_{18} \mathrm{~N}_{2} \mathrm{O}\left([\mathrm{M}]^{+}\right.$) 206.1419, found 206.1351 .

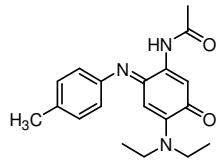

$N$-\{4-Diethylamino-3-oxo-6-[p-tolylimino]-cyclohexa-1,4-dienyl\}-acetamide (5a). To $50 \mathrm{~mL}$ of water in a $250 \mathrm{~mL}$ conical flask equipped with a magnetic stir bar was added a solution of $\mathbf{3}(5 \mathrm{~mL}, 0.2 \mathrm{M}, \mathrm{MeCN}, 1$ eqv) followed by a

solution of $p$-toluidine $(5 \mathrm{~mL}, 0.2 \mathrm{M}, \mathrm{MeCN}, 1 \mathrm{eqv})$. While stirring rapidly, the resulting solution was treated all at once with an aqueous solution of $\mathrm{NaIO}_{4}(10 \mathrm{~mL}, 0.5 \mathrm{M}, 10 \mathrm{eqv})$. Upon addition of the oxidant, a bright red/purple color was noted, followed immediately by the presence of a dark red precipitate. After $10 \mathrm{~min}$ of stirring at $\mathrm{rt}$, the precipitate was isolated by centrifugation
} 
(discarding the mother liquor). The precipitate was washed three times with $25 \mathrm{~mL}$ of water by rounds of resuspension and centrifugation. The precipitate was dissolved in a minimal volume of EtOAc which was then dried over $\mathrm{Na}_{2} \mathrm{SO}_{4}$. Flash chromatography (EtOAc:Hexanes) afforded $186 \mathrm{mg}$ of $\mathbf{5 a}$ as a pure red/purple solid (57\% yield): ${ }^{1} \mathrm{H}$ NMR $\left(500 \mathrm{MHz}, \mathrm{CD}_{3} \mathrm{CN}\right): \delta, 1.07(\mathrm{t}, 6 \mathrm{H}, J=7.0 \mathrm{~Hz}), 2.16(\mathrm{~s}, 3 \mathrm{H}), 2.35$ (s, $3 \mathrm{H}), 3.30(\mathrm{q}, 4, J=7.0 \mathrm{~Hz}), 5.60(\mathrm{~s}, 1 \mathrm{H}), 6.88(\mathrm{~d}, 2 \mathrm{H}, J=8.0), 7.23(\mathrm{~d}$, $2 \mathrm{H}, J=8.0 \mathrm{~Hz}), 7.27(\mathrm{~s}, 1 \mathrm{H}), 9.33(\mathrm{~s}, 1 \mathrm{H}) .{ }^{13} \mathrm{C} \mathrm{NMR}(125 \mathrm{MHz}$, $\left.\mathrm{CD}_{3} \mathrm{CN}\right): \delta, 12.0,19.9,24.2,44.8,94.3,112.3,121.0,129.5,134.2$, Vis.

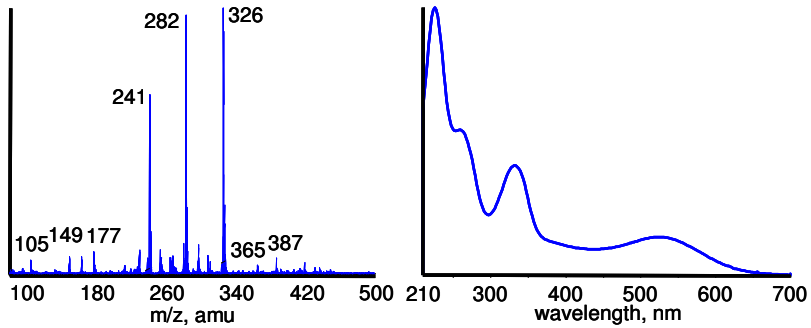

Figure S2. Spectral characteristics of 5a. (left) ESI-MS, (right) UV-

142.0, 146.1, 147.0, 152.1, 169.6, 185.6.

O-18 Enriched: $\boldsymbol{N}$-\{4-Diethylamino-3-oxo-6-[p-tolylimino]-cyclohexa-1,4-dienyl\}-acetamide (5b). To a $100 \mu \mathrm{L}$
solution of $\mathrm{NaIO}_{4}\left(320 \mathrm{mM}\right.$ in ${ }^{18} \mathrm{OH}_{2}(98 \%$ enrichment, Aldrich), 8 eqv $)$ in a $600 \mu \mathrm{L}$ eppendorf tube was added $40 \mu \mathrm{L}$ of mixed briefly by vortex. After $15 \mathrm{~min}$, the reaction mixture was centrifuged at 16,000 rcf for 5 min. The supernatant (light orange) was carefully removed from the precipitate by pipette and the residual solvent was removed under reduced pressure. The red solid was dissolved in $200 \mu \mathrm{L}$ of EtOAc and $\mathbf{5 b}\left(0.6 \mathrm{mg}, 46 \%\right.$ yield) was isolated by flash chromatography (EtOAc:Hexanes): ${ }^{1} \mathrm{H} \mathrm{NMR}(500 \mathrm{MHz}$, $\left.\mathrm{CD}_{3} \mathrm{CN}\right): \delta, 1.07(\mathrm{t}, 6 \mathrm{H}, J=7.0 \mathrm{~Hz}), 2.16(\mathrm{~s}, 3 \mathrm{H}), 2.35(\mathrm{~s}, 3 \mathrm{H}), 3.30(\mathrm{q}, 4, J=7.0 \mathrm{~Hz}), 5.61(\mathrm{~s}, 1 \mathrm{H}), 6.88(\mathrm{~d}, 2 \mathrm{H}, J=8.0), 7.23(\mathrm{~d}, 2 \mathrm{H}, J=$ $8.0 \mathrm{~Hz}), 7.27(\mathrm{~s}, 1 \mathrm{H}), 9.33(\mathrm{~s}, 1 \mathrm{H})$.

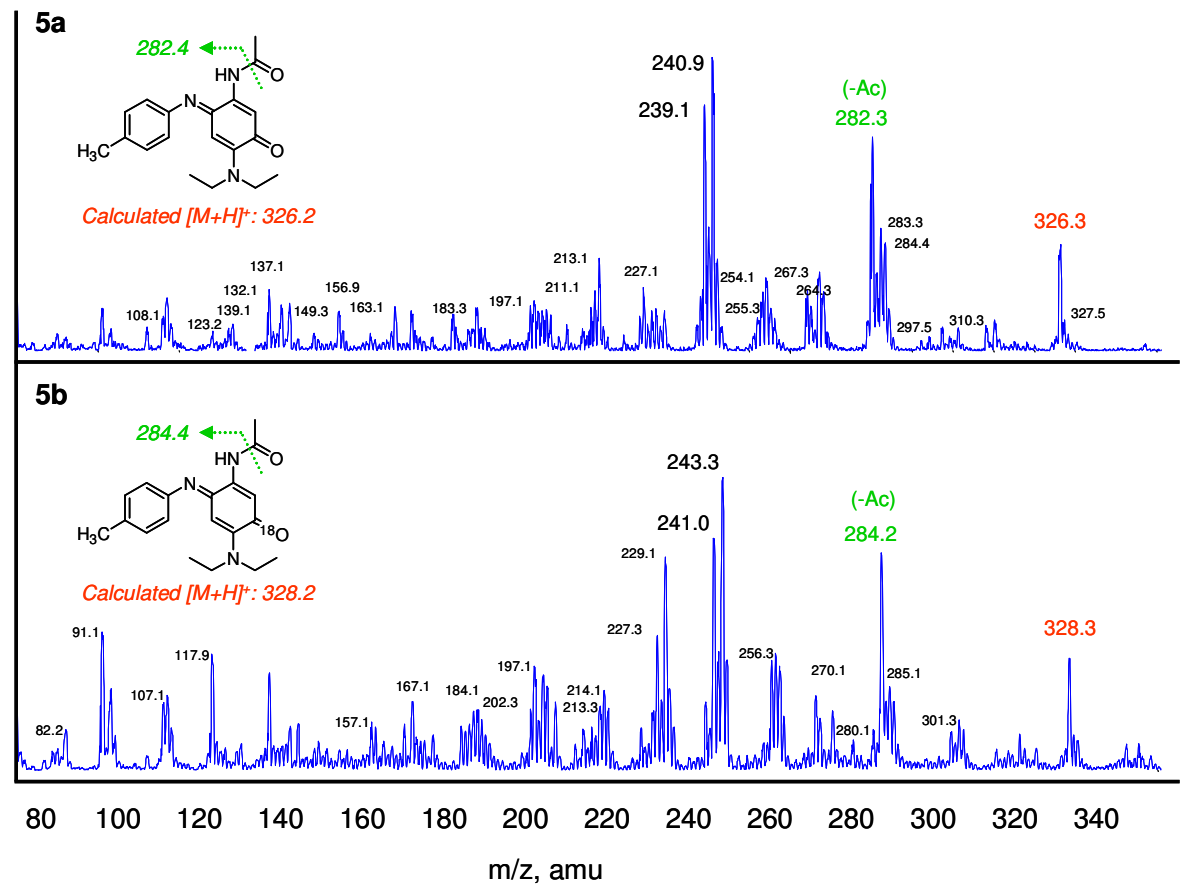

Figure S3. Isotopic incorporation of ${ }^{18} \mathrm{O}$. (top) ESI-MS of 5a (synthesis carried out in ${ }^{16} \mathrm{OH}_{2}$ ). (bottom) ESI-MS of $\mathbf{5 b}$ (synthesis carried out in ${ }^{18} \mathrm{OH}_{2}$ ). The presence of the isotope is noted in the parent ion (red) as well as several fragment ions. Of note, the fragment ion resulting from the loss of acetate (green) carries the isotopic incorporation. Upon incubation of $\mathbf{5 b}$ in $50: 50 \mathrm{MeCN}:{ }^{16} \mathrm{OH}_{2}$ for $24 \mathrm{~h}$, no isotope exchange was observed by ESI-MS. 
$N$-\{6-[4-Bromo-phenylimino]-4-diethylamino-3-oxo-cyclohexa-1,4-dienyl\}-acetamide (S1). To $10 \mathrm{~mL}$ of water in a $50 \mathrm{~mL}$ centrifuge tube was added a solution of $p$-bromoaniline $(0.5 \mathrm{~mL}, 0.2 \mathrm{M}, \mathrm{MeCN}, 1 \mathrm{eqv})$ followed by a solution of 3 ( $0.5 \mathrm{~mL}, 0.2 \mathrm{M}, \mathrm{MeCN}, 1 \mathrm{eqv})$. While stirring rapidly, the resulting suspension was treated all at once with an aqueous solution of $\mathrm{NaIO}_{4}(1.0 \mathrm{~mL}, 0.5 \mathrm{M}, 10 \mathrm{eqv})$. After $20 \mathrm{~min}$ of agitation on a rotating shaker, the precipitate was isolated by centrifugation (discarding the mother liquor). The precipitate was dissolved in a minimal volume of $\mathrm{MeCN}$ and $\mathbf{S 1}$ was isolated by reversed-phase chromatography $\left(\mathrm{H}_{2} \mathrm{O}: \mathrm{MeCN}\right.$ with $0.1 \%$ TFA) affording $21 \mathrm{mg}(54 \%$ yield). ${ }^{1} \mathrm{H}$ NMR (500 MHz, $\left.\mathrm{CD}_{3} \mathrm{CN}\right): \delta, 1.07$ (t, 6H, $\left.J=7.0 \mathrm{~Hz}\right) 2.16$ (s, 3H), $3.32(\mathrm{q}, 4 \mathrm{H}, J=7.0 \mathrm{~Hz}), 5.46(\mathrm{~s}, 1 \mathrm{H}), 6.88(\mathrm{~d}, 2 \mathrm{H}, J=8.5 \mathrm{~Hz})$, 7.27 (s, 1H), 7.55 (d, 2H, J = 8.5 Hz), 9.25 (br s, 1H). ${ }^{13} \mathrm{C}$ NMR (125 $\left.\mathrm{MHz}, \mathrm{CD}_{3} \mathrm{CN}\right): \delta, 12.0,24.2,45.9,93.4,112.4,116.7,123.0,131.9$,

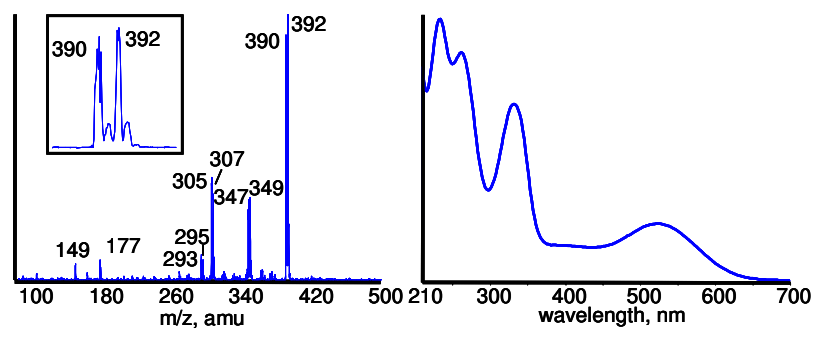

Figure S4. Spectral characteristics of S1. (left) ESI-MS, (right) UVVis.

$141.9,146.3,152.9,169.7,185.5$.

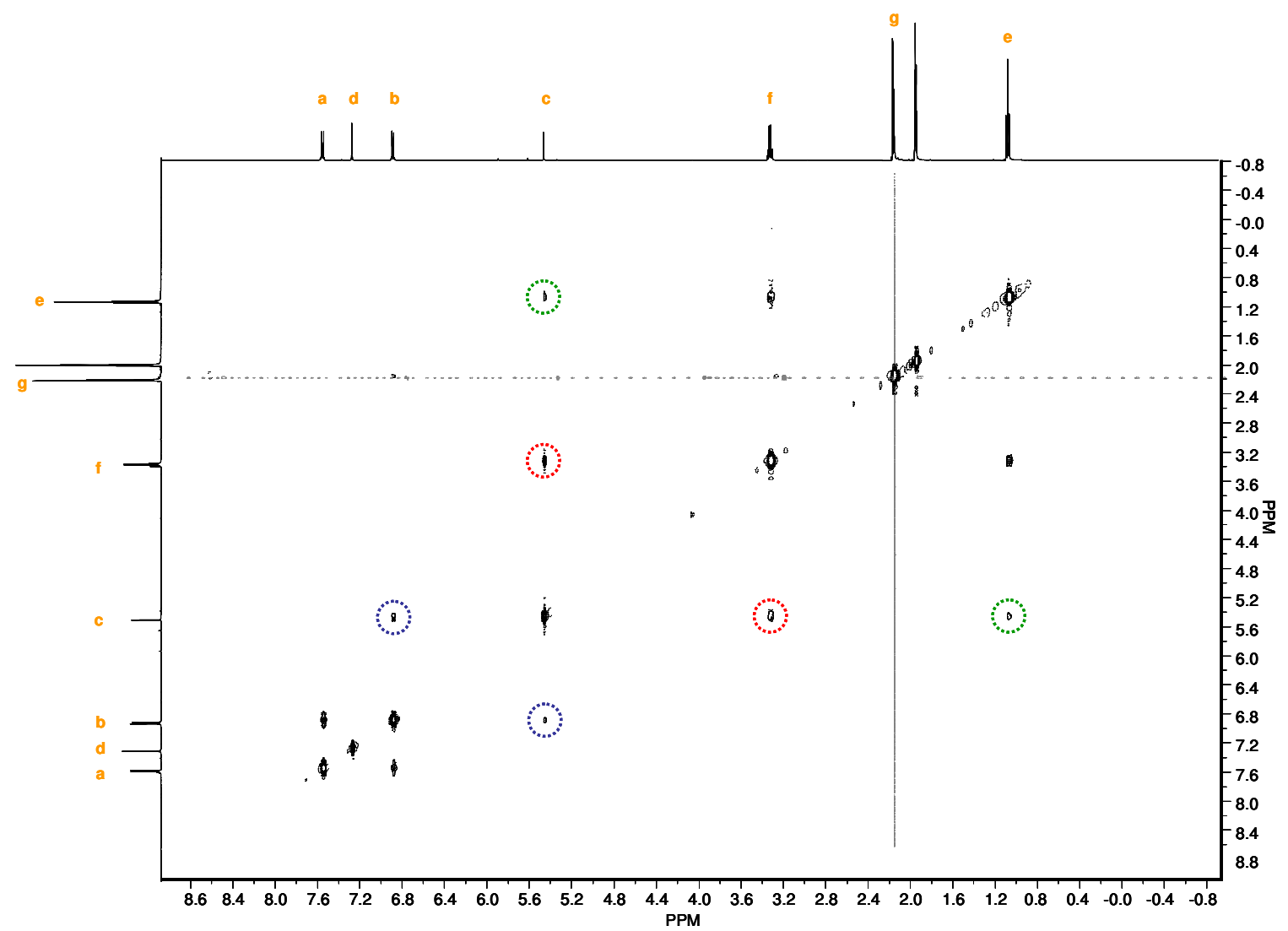

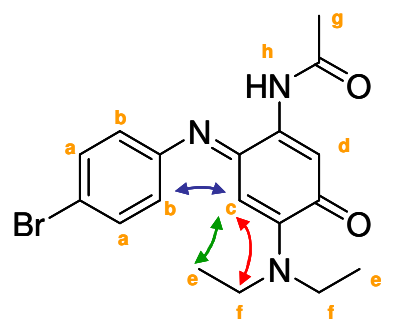

Figure S5. ${ }^{1} \mathrm{H}-\mathrm{NOESY}$ characterization of S1. In order to clearly differentiate ${ }^{1} \mathrm{H}$ signals, S1 was synthesized as a structural analog of 5a. The regiochemical assignment of oxidative coupling products was made primarily due to the nOe signals highlighted with colored circles. The spectrum was taken in $\mathrm{CD}_{3} \mathrm{CN}$ at $500 \mathrm{MHz}$. 
5-Amino-2-methyl-4-[p-tolylimino]-cyclohexa-2,5-dienone (S2, major byproduct formed from oxidative
coupling). Dimerization of $p$-toluidine through a pathway analogous to the formation of 5a is observed during small molecule coupling reactions. Isolation of $\mathbf{S} 2$ was accomplished during purification of 5a (in earlier eluting fractions). The yield of $\mathbf{S 2}$ varies from reaction to reaction but is generally represents about $10 \%$ of the total mass isolated. ${ }^{1} \mathrm{H}$ NMR (500 MHz, $\mathrm{CD}_{3} \mathrm{CN}$ ): $\delta, 2.23$ (s, 3H), 2.34 (s, 3H), 4.94 (br s, 2H), 5.86 (s, 1H), 6.46 (s, 1H), 6.71 (d, 2H, $J=8.0$ $\mathrm{Hz}), 7.20$ (d, $2 \mathrm{H}, J=8 \mathrm{~Hz}) .{ }^{13} \mathrm{C}$ NMR (125 MHz, $\left.\mathrm{CD}_{3} \mathrm{CN}\right): \delta, 17.1$, 19.8, 95.1, 120.0, 128.1, 129.3, 133.6, 144.0, 148.9, 151.4, 159.0, 183.4.

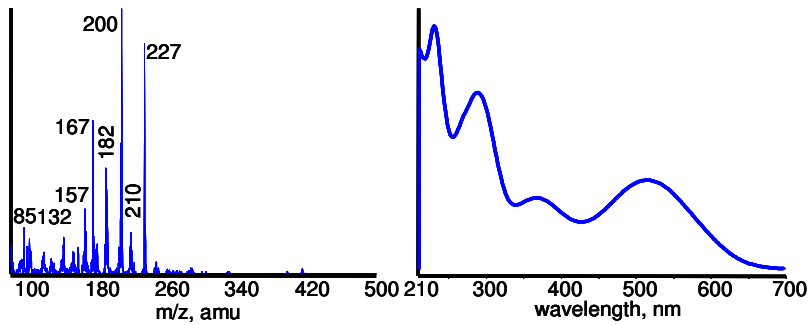

Figure S6. Spectral characteristics of S2. (left) ESI-MS, (right) UVVis.
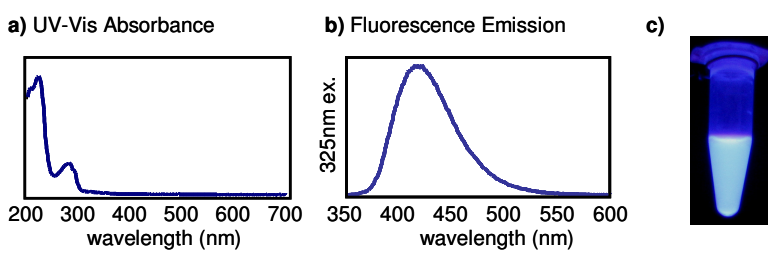

Figure S7. Spectral characteristics of lysozyme anthranilamide, 8. (a) UV-Vis spectrum of 8, $10 \mu \mathrm{M}, \mathrm{pH} \quad 6.5 \mathrm{NaH}_{2} \mathrm{PO}_{4}$ buffer. (b) Fluorescence emission spectrum of $8,1 \mu \mathrm{M}, \mathrm{pH} 6.5 \mathrm{NaH}_{2} \mathrm{PO}_{4}$ buffer. (c) Digital picture of $8(50 \mu \mathrm{M})$ excited with $306 \mathrm{nM}$ light.

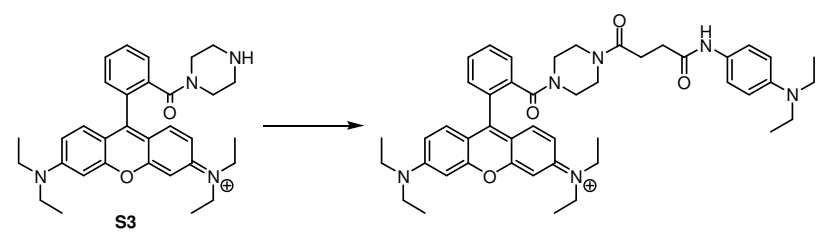

followed by succinic anhydride (20.1 $\mathrm{mg}, 0.20 \mathrm{mmol}, 1.05 \mathrm{eqv})$. Reaction progress was monitored by MALDI-TOF MS. After $25 \mathrm{~min}$, the reaction solution was treated with $\mathrm{N}, \mathrm{N}$-diethyl- $p$-phenylenediamine $(94 \mathrm{mg}, 0.57 \mathrm{mmol}, 3.0 \mathrm{eqv}$ ) and dicyclohexylcarbodiimide (DCC, 79 $\mathrm{mg}, 0.38 \mathrm{mmol}, 2 \mathrm{eqv})$. After $1.5 \mathrm{~h}$ at $\mathrm{rt}$, the intermediate acid had been converted to 14a as determined by MALDI-TOF MS, and the solvent was removed under reduced pressure. The resulting purple residue was dissolved in $75 \mathrm{~mL}$ of $5 \% \mathrm{NaHCO}_{3}$ solution and washed with three $50 \mathrm{~mL}$ portions of EtOAc (discarding the organic layers). The aqueous solution was saturated with $\mathrm{NaCl}$ and extracted with three $100 \mathrm{~mL}$ portions of 2:1 $\mathrm{iPrOH}: \mathrm{CH}_{2} \mathrm{Cl}_{2}$. The organic layers were combined, dried over $\mathrm{Na}_{2} \mathrm{SO}_{4}$, and concentrated under reduced pressure to afford 14a (101 mg, 70\% yield) in sufficient purity ( $>90 \%)$ for protein labeling. For compound characterization, further purification of 14a was achieved by flash chromatography $\left(\mathrm{CH}_{2} \mathrm{Cl}_{2}: \mathrm{MeOH}\right.$ gradient elution with $0.1 \%$ acetic acid in the mobile phase). ${ }^{1} \mathrm{H}$ NMR (400 MHz, CD 3 OD): $\delta, 1.11(\mathrm{t}, 6 \mathrm{H}, J=7.0 \mathrm{~Hz}), 1.30(\mathrm{t}, 12 \mathrm{H}, J=7.0 \mathrm{~Hz}), 2.61(\mathrm{t}, 2 \mathrm{H}, J=6.0 \mathrm{~Hz}), 2.66(\mathrm{t}, 2 \mathrm{H}, J=6.0 \mathrm{~Hz}) 3.35(\mathrm{~m}$, $8 \mathrm{H}), 3.42(\mathrm{q}, 4 \mathrm{H}, J=6.0 \mathrm{~Hz}), 3.67(\mathrm{q}, 8 \mathrm{H}, J=7.0 \mathrm{~Hz}), 6.66(\mathrm{~d}, 2 \mathrm{H}, J=8.0 \mathrm{~Hz}), 6.96(\mathrm{~d}, 2 \mathrm{H}, J=2.0 \mathrm{~Hz}), 7.07$ (br d, $2 \mathrm{H}, 8.0 \mathrm{~Hz}), 7.17(\mathrm{~m}$, 1H), 7.28 (app d, 4H, $J=9.5 \mathrm{~Hz}), 7.52($ br s, $1 \mathrm{H}), 7.70(\mathrm{~m}, 1 \mathrm{H}), 7.77(\mathrm{~m}, 2 \mathrm{H}) .{ }^{13} \mathrm{C} \mathrm{NMR}\left(125 \mathrm{MHz}, \mathrm{CD}_{3} \mathrm{OD}\right): \delta, 11.3,11.6,22.3,44.3$, 45.4, 47.8, 48.4, 48.6, 95.9, 112.7, 113.4, 114.0, 121.8, 127.5, 127.8, 128.5, 129.8, 129.9, 130.3, 131.7, 135.1, 146.0, 155.8, 157.8, 171.1, 171.5, 179.7. HRMS (MALDI-TOF) calculated for $\mathrm{C}_{46} \mathrm{H}_{57} \mathrm{~N}_{6} \mathrm{O}_{4}\left([\mathrm{M}]^{+}\right)$757.9826, found 757.9901. 


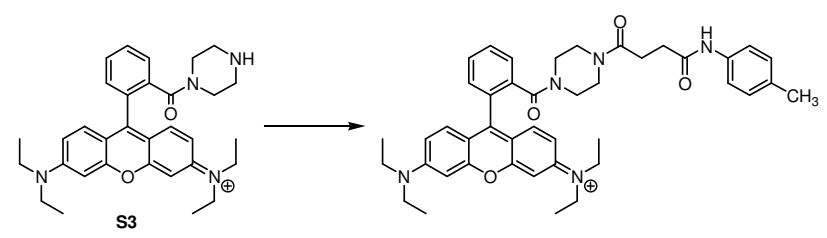

Rhodamine B-toluidine conjugate (14b). To a stirred solution of Rhodamine B-piperazine amide $\mathbf{S 3}^{1}$ (100 $\mathrm{mg}, 0.183 \mathrm{mmol}, 1.0$ eqv) in 5 $\mathrm{mL}$ of $\mathrm{CH}_{2} \mathrm{Cl}_{2}$ at $\mathrm{rt}$ was added $50 \mu \mathrm{L}$ diisopropylethyl amine (DIPEA). The resulting solution was treated with solid N,Ndimethylaminopyridine (DMAP, $6 \mathrm{mg}, 0.049 \mathrm{mmol}, 0.37 \mathrm{eqv}$ ) followed by succinic anhydride $(27.5 \mathrm{mg}, 0.275 \mathrm{mmol}, 1.5 \mathrm{eqv})$. Reaction progress was monitored by MALDI-TOF MS. After $15 \mathrm{~min}$, the reaction solution was treated with p-toluidine (59 mg, $0.550 \mathrm{mmol}, 3.0 \mathrm{eqv}$ ) and dicyclohexylcarbodiimide (DCC, $188 \mathrm{mg}, 0.915 \mathrm{mmol}, 5 \mathrm{eqv})$. After $12 \mathrm{~h}$ at $\mathrm{rt}$, the intermediate acid had been converted to $\mathbf{1 4 b}$ (as determined by MALDI-TOF MS) and the solvent was removed under reduced pressure. The resulting purple residue was dissolved in $75 \mathrm{~mL}$ of $5 \% \mathrm{NaHCO}_{3}$ solution and washed with three $50 \mathrm{~mL}$ portions of EtOAc (discarding the organic layers). The aqueous solution was saturated with $\mathrm{NaCl}$ and extracted with three $100 \mathrm{~mL}$ portions of 2:1 $i \mathrm{PrOH}: \mathrm{CH}_{2} \mathrm{Cl}_{2}$. The organic layers were combined, dried over $\mathrm{Na}_{2} \mathrm{SO}_{4}$, and concentrated under reduced pressure. Purification of $\mathbf{1 4 \mathbf { b }}$ was achieved by flash chromatography (EtOAc:MeOH gradient elution with $0.1 \%$ trifluoroacetic acid in the mobile phase) affording $91 \mathrm{mg}$ (71\% yield). ${ }^{1} \mathrm{H}$ NMR (400 MHz, $\left.\mathrm{CD}_{3} \mathrm{OD}\right): \delta, 1.28(\mathrm{t}, 12 \mathrm{H}, J=6.8 \mathrm{~Hz}), 2.27$ (s, 3H), $2.64(\mathrm{~m}, 4 \mathrm{H}), 3.28-3.40(\mathrm{br}, 8 \mathrm{H}), 3.65(\mathrm{q}, 8 \mathrm{H}, J=7.2$ Hz), $6.95(\mathrm{~d}, 2 \mathrm{H}, J=2.3 \mathrm{~Hz}), 7.07(\mathrm{app} \mathrm{t}, 3 \mathrm{H}, J=8.0 \mathrm{~Hz}), 7.27(\mathrm{~d}, 2 \mathrm{H}, J=9.6 \mathrm{~Hz}), 7.36$ (d, 2H, 8.4 Hz), 7.50 (br s, 1H), $7.70-7.75$ (br, $3 \mathrm{H}) .{ }^{13} \mathrm{C} \mathrm{NMR}\left(125 \mathrm{MHz}, \mathrm{CD}_{3} \mathrm{OD}\right): \delta, 11.3,19.4,27.3,27.9,30.9,41.5,45.5,96.0,113.4,114.0,119.8,126.5,127.5,128.7,129.1,129.8$, $129.9,130.3,131.8,133.2,135.1,135.9,155.8,157.8,168.0,170.6,177.2$. HRMS (MALDI-TOF) calculated for $\mathrm{C}_{43} \mathrm{H}_{50} \mathrm{~N}_{5} \mathrm{O}_{4}\left([\mathrm{M}]^{+}\right)$ 700.3857 , found 700.3874 .

Protein labeling with 3-p-(aminophenyl)propionic acid $(\mathbf{1 1}, \mathbf{1 3})$. To a $1.0 \mathrm{~mL}$ stirred solution of 3-p(aminophenyl)propionic acid (25 mM, DMF, 1 eqv)

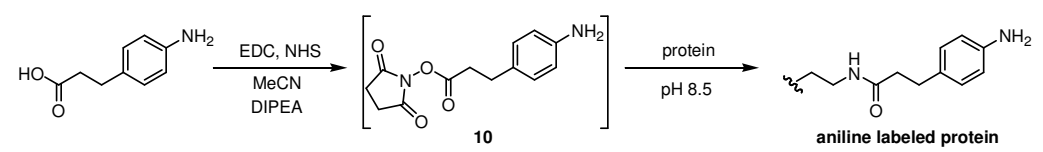
was added N-hydroxysuccinimide ( $8.6 \mathrm{mg}, 75 \mu \mathrm{mol}, 3 \mathrm{eqv}$ ) followed by $\mathrm{N}$-(3-dimethylaminopropyl)-N'-ethylcarbodiimide, hydrochloride (EDC, $7.2 \mathrm{mg}, 38 \mu \mathrm{mol}, 1.5 \mathrm{eqv}$ ). After stirring for $15 \mathrm{~min}$ at rt, a $50 \mu \mathrm{L}$ aliquot of $\mathbf{1 0}$ was added to $1.0 \mathrm{~mL}$ of a buffered solution of protein $\left(125 \mu \mathrm{M}, 100 \mathrm{mM} \mathrm{NaH} \mathrm{PO}_{4} / 25 \mathrm{mM} \mathrm{NaOAc}, \mathrm{pH}\right.$ 8.5). The resulting solution was mixed on a rotating shaker for $3 \mathrm{~h}$ at rt. Purification of the protein was accomplished by gel-filtration chromatography using a NAP-10 column (Amersham) with $100 \mathrm{mM}$ $\mathrm{NaH}_{2} \mathrm{PO}_{4}, \mathrm{pH} 6.5$, as the eluent. The extent of protein labeling was determined to be $70 \%$ for 11 and $62 \%$ for $\mathbf{1 3}$ by LC-MS.

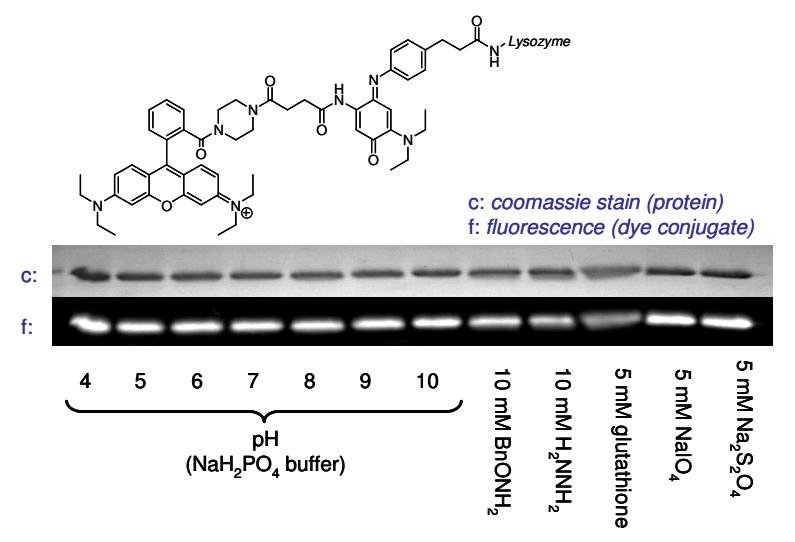

Figure S8. Chemical stability of protein conjugates. Samples of lysozyme modified with 14a were incubated for $24 \mathrm{~h}$ at rt under the conditions above. Little if any detachment of the fluorophore from the protein was observed by SDS-PAGE.

General procedure for oxidative coupling with proteins containing aniline functional groups. To a $100 \mu \mathrm{L}$ sample of aniline bearing protein $\left(50 \mu \mathrm{M}, \mathrm{pH} 6.5,0.1 \mathrm{M} \mathrm{NaH}_{2} \mathrm{PO}_{4}\right)$ was added $1.0 \mu \mathrm{L}$ of $N, N$-dialkyl- $N$ '-acyl-p-phenylenediamine substrate (such as 3 or $\left.\mathbf{1 4 a}\right)(50$ 
$\mathrm{mM}$ in $\mathrm{MeCN}$ or DMF). The solution was mixed briefly by vortex and treated with $1.0 \mu \mathrm{L}$ of an aqueous solution of $\mathrm{NaIO}_{4}(150 \mathrm{mM})$. Purification was accomplished by passing the solution through size-exclusion media (typically G25, Amersham Biosciences).

Construction of mEGFP-V2G-pTXB1 plasmid. The EGFP gene was amplified out of EGP-V2G-pET28b using primers 5'GGTGGTCATATGGGCAGCAAGGGC - 3' and 5' - GGTGGTTGCTCTTCCGCACTTGTACAGCT - 3', placing a Sap I restriction site at the C-terminus. The PCR product was digested with Nde I and Sap I and placed into the pTXB1 vector (New England Biolabs) which contains an ampicillin resistance gene. The identity of the ligation product was verified by sequencing. Quick Change Mutagenesis (Stratagene, CA) was performed using primers 5'-CACTACCTGAGCACCCAGTCCAAGCTGAGCAAAGACCCCAACGAG - 3' and 5' - CTCGTTGGGGTCTTTGCTCAGCTTGGACTGGGTGCTCAGGTAGTG -3' in order to create mutant A206K, a mutation known to suppress dimerization of EGFP.

Expression of mEGFP (15). EGFP plasmids were transformed into E. coli Tuner ${ }^{\mathrm{TM}}$ cells BL21 (DE3) pLysS via electroporation utilizing a Micro-Pulser (Biorad, CA) and plated on LB Agarose Plates (ampicillin $100 \mu \mathrm{g} / \mathrm{mL}$ ). Cells were grown in $500 \mathrm{~mL}$ Lurea Broth (LB) at $37^{\circ} \mathrm{C}$ until an optical density (OD) of 0.5 was observed at $600 \mathrm{~nm}$. The LB contained the antibiotic ampicillin $100 \mu \mathrm{g} / \mathrm{ml}$. Induction of EGFP expression occurred by the addition of $0.1 \mathrm{mM}$ isopropyl- $\beta-D-$ thiogalactopyranoside (IPTG). Cultures were grown for an additional $16 \mathrm{~h}$ at $25{ }^{\circ} \mathrm{C}$. The cells were then spun down for $20 \mathrm{~min}$ at $7000 \mathrm{rcf}$ at $4{ }^{\circ} \mathrm{C}$. Protein expression was verified by the presence of a green fluorescent cell pellet as well as the identity of the desired protein band by SDS-PAGE. The cells were then re-suspended in $10 \mathrm{~mL}$ of Lysis Buffer (0.02 M Tris, $0.15 \mathrm{M} \mathrm{NaCl}, 5 \mathrm{mM}$ EDTA, pH 8.0) by vortexing. The cells were lysed by sonication using a Branson Digital Sonifier (VWR Scientific) for $20 \mathrm{~min}$ with a blunt ended tip. Debris was removed by centrifugation at 10,000 rcf for $1 \mathrm{~h}$ to give a transparent green solution.

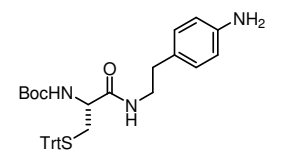

After an additional $30 \mathrm{~min}$ of stirring, the DMF was removed by rotary evaporation and the resulting yellow oil was dissolved in $20 \mathrm{~mL}$ EtOAc. The solution was washed with three $50 \mathrm{~mL}$ portions of water, followed by two $50 \mathrm{~mL}$ portions of $0.1 \mathrm{M} \mathrm{NaHSO}_{4}$ solution, $30 \mathrm{~mL}$ of saturated $\mathrm{NaHCO}_{3}$ solution, and $50 \mathrm{~mL}$ of brine. The organic layer was dried with $\mathrm{Na}_{2} \mathrm{SO}_{4}$. Purification by flash chromatography $\left(\mathrm{CH}_{2} \mathrm{Cl}_{2}: \mathrm{MeOH}\right)$ afforded $0.82 \mathrm{~g}$ of $\mathbf{S 4}$ as a yellow solid $(65 \%$ yield $):{ }^{1} \mathrm{H} \mathrm{NMR}\left(400 \mathrm{MHz}, \mathrm{CDCl}_{3}\right): \delta, 1.30(\mathrm{~s}, 9 \mathrm{H}), 2.54(\mathrm{dd}, 1 \mathrm{H}, J=4.8$ $\mathrm{Hz}, 12.0 \mathrm{~Hz}), 2.67(\mathrm{t}, 2 \mathrm{H}, J=6.8 \mathrm{~Hz}), 2.74(\mathrm{~s}, 1 \mathrm{H}), 3.42(\mathrm{~m}, 2 \mathrm{H}, J=6.8 \mathrm{~Hz}), 3.78(\mathrm{~s}, 1 \mathrm{H}), 4.82(\mathrm{~s}, 1 \mathrm{H}), 5.95(\mathrm{~s}, 1 \mathrm{H}), 6.60(\mathrm{~d}, 2 \mathrm{H}, J=8.0$ $\mathrm{Hz}), 6.96(\mathrm{~d}, 2 \mathrm{H}, J=8.0 \mathrm{~Hz}), 7.24-7.34(\mathrm{~m}, 9 \mathrm{H}) 7.45(\mathrm{~d}, 6 \mathrm{H}, J=8.0 \mathrm{~Hz}) .{ }^{13} \mathrm{C} \mathrm{NMR}\left(100 \mathrm{MHz}, \mathrm{CDCl}_{3}\right): \delta, 28.3,34.1,34.6,53.7,67.2$, 80.2, 115.5, 126.9, 128.1, 128.7, 129.6, 155.2, 170.2. LRMS (FAB) calculated for $\mathrm{C}_{12} \mathrm{H}_{18} \mathrm{~N}_{2} \mathrm{O}\left([\mathrm{M}+\mathrm{H}]^{+}\right)$582.7, found 582.3.

Deprotection to afford cysteine amide 16: The Boc and trityl protecting groups were removed from $\mathbf{S 4}$ by adding sequentially $0.9 \mathrm{~mL}$ of trifluoroacetic acid (TFA), $0.05 \mathrm{~mL}$ of $\mathrm{H}_{2} \mathrm{O}$ and $0.05 \mathrm{~mL}$ of triisopropylsilane (TIPS) to an appropriate amount of solid for use in subsequent chemistry. Upon addition of TFA the solution became amber, and with addition of TIPS a white precipitate formed. The volatile components were removed by evaporation under a stream of $\mathrm{N}_{2}$. To the dried product another $1.0 \mathrm{~mL}$ of TFA was added and again evaporated. The dried material was resuspended in $1.0 \mathrm{~mL}$ of $\mathrm{diH}_{2} \mathrm{O}$ and any residual precipitate was removed by filtration $(0.45$ micron syringe filter). The yellow solution was lyophilized overnight to afford 16, which was carried on without further purification.

Modification and Purification of mEGFP (17). mEGFP was purified utilizing a $25 \mathrm{ml}$ fritted column loaded with 5-10 mL of Chitin Resin (NEB). Lysate was washed over the resin under mild suction. The resulting resin-bound protein was washed with $100 \mathrm{~mL}$ of Wash 
Buffer (Tris .02M, NaCl 0.5 M, EDTA $1 \mathrm{mM}, \mathrm{pH} 7.5$ ). Binding to the column was confirmed by SDS-PAGE analysis of the eluent and by the green color of the resulting chitin. A $20 \mathrm{~mL}$ solution containing $50 \mathrm{mM}$ mercaptoethane sulfate (MESNA) or a solution of $50 \mathrm{mM}$ MESNA and 20mM 16 in Wash Buffer (adjusted pH to 7.5) was flowed over the resin bound protein using suction. The column bed was allowed to stand in this solution at rt. for $36 \mathrm{~h}$ with protection from light. Protein was eluted from the column with addition of $20 \mathrm{~mL}$ of Wash Buffer. Purified protein was then buffer exchanged into $25 \mathrm{mM}$ phosphate buffer (pH 6.5), to remove free MESNA and 16, using Amicon Ultra 15mL 10,000 MWCO (Millipore) spin concentrators.

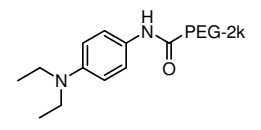

$N, N$-Diethyl-p-phenylenediamine- $N$ '-poly(ethylene glycol) amide (Average $\mathbf{M W}=\mathbf{2 0 0 0 )}$ (18). Trioctylamine (21 $\mu \mathrm{L}, 50 \mu \mathrm{mol})$ was added dropwise to a stirred solution of the following: Poly(ethylene glycol) NHS Ester (M-PEGSPA-2K Nektar) $(50 \mathrm{mg}, 25 \mu \mathrm{mol}), N, N$-diethyl- $p$-phenylenediamine $(23 \mathrm{mg}, 125 \mu \mathrm{mol})$ and DMAP $(3.4 \mathrm{mg}, 25$ $\mu \mathrm{mol})$ in $\mathrm{CH}_{2} \mathrm{Cl}_{2}(1 \mathrm{~mL})$ at $\mathrm{rt}$. The resulting solution was stirred overnight at $\mathrm{rt}$. Purification was achieved by addition of the reaction mixture to $100 \mathrm{~mL}$ or $\mathrm{Et}_{2} \mathrm{O}$ in a $1 \mathrm{~L}$ r.b. flask which was roto-evaporated to dryness. Material was washed with $4 \mathrm{X} 100 \mathrm{~mL} \mathrm{Et} \mathrm{O}_{2} \mathrm{O}$ until wash was clear, which afforded $0.42 \mathrm{~g}$ of $\mathbf{1 8}$ as a faint purple solid $\left(81 \%\right.$ yield): ${ }^{1} \mathrm{H} \mathrm{NMR}\left(400 \mathrm{MHz}, \mathrm{CDCl}_{3}\right): \delta, 1.12(\mathrm{t}, 6 \mathrm{H}, J=7.2 \mathrm{~Hz}), 2.61(\mathrm{t}$, $2 \mathrm{H}, \mathrm{J}=5.6 \mathrm{~Hz}), 3.28(\mathrm{q}, 4 \mathrm{H}, J=7.2 \mathrm{~Hz}), 3.67(\mathrm{~m}, \sim 182 \mathrm{H}), 6.62(\mathrm{~d}, 2 \mathrm{H}, J=8.8 \mathrm{~Hz}), 7.34(\mathrm{~d}, 2 \mathrm{H}, J=8.8 \mathrm{~Hz})$.

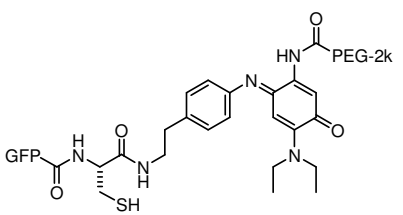

The results were then analyzed by SDS-PAGE (12\% Gel) with Coomassie staining. Percentage modification was determined using Image-J software.

General Procedure for Pegylation of mEGFP with Oxidative Coupling (19). To a solution of eGFP ( $50 \mu \mathrm{M}$ in $25 \mathrm{mM}$ phosphate buffer, $\mathrm{pH} 6.5$ ) was added a solution of $\mathbf{1 8}$ in $\mathrm{H}_{2} \mathrm{O}$ (final concentration 133 $\mu \mathrm{M}$ ) and a solution of $\mathrm{NaIO}_{4}$ in $\mathrm{H}_{2} \mathrm{O}$ (final concentration $500 \mu \mathrm{M}$ ) The resulting solution was left for 2 $\mathrm{h}$, and then fluorescence was measured or the reaction was quenched by the addition of loading buffer.

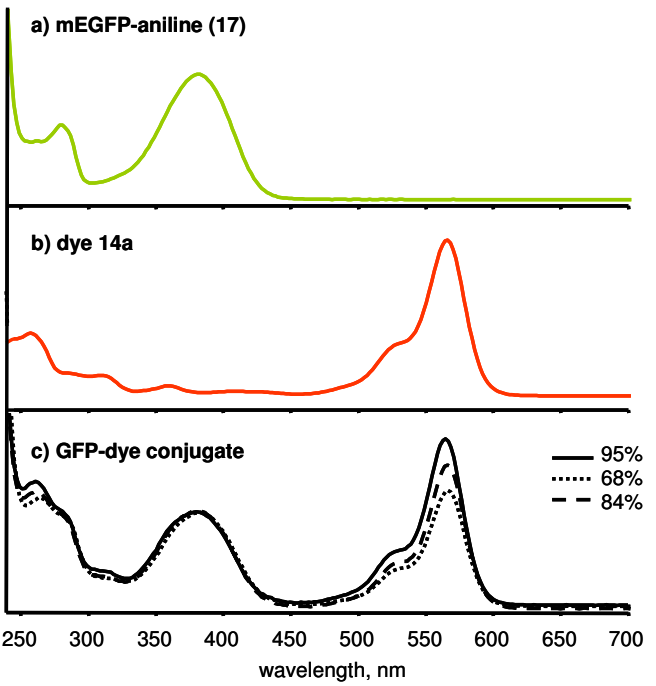

Figure S9. Reaction of 14a with mEGFP aniline (17). mEGFP-aniline (17, $300 \mu \mathrm{L}, 50 \mu \mathrm{M}, 0.1$ $\left.\mathrm{M} \mathrm{NaH}_{2} \mathrm{PO}_{4} \mathrm{pH} 6.5\right)$ was incubated with 14a $(250 \mu \mathrm{M})$. The solution was divided into 6 aliquots. Three were treated with $\mathrm{NaIO}_{4}(1 \mathrm{mM})$ and three had no oxidant added. After $2 \mathrm{~h}$, each solution was passed through two G25 columns (Amersham). The samples were then analyzed by UV-Vis. a) UV-Vis spectrum of 17. b) UV-Vis spectum of 14a. c) UV-Vis spectra of GFP-dye conjugates. The percent labeling is indicated for the three replicate samples (assumes GFP $\varepsilon$ 55K : 14a $\varepsilon$ 95K). The three samples with no oxidant were determined to give a small background signal corresponding to $2-7 \%$ labeling. 
a)

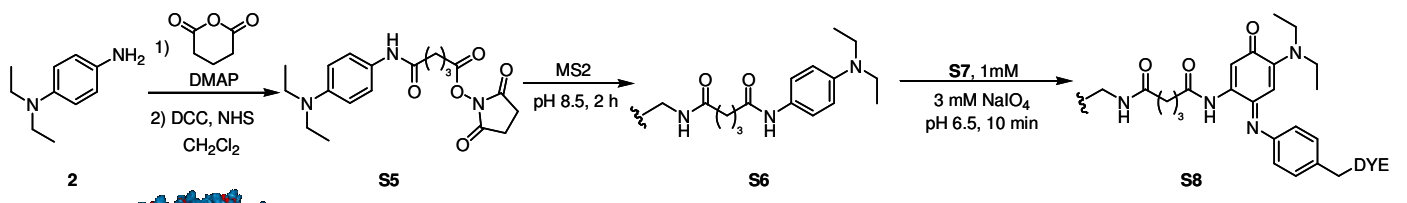

b)
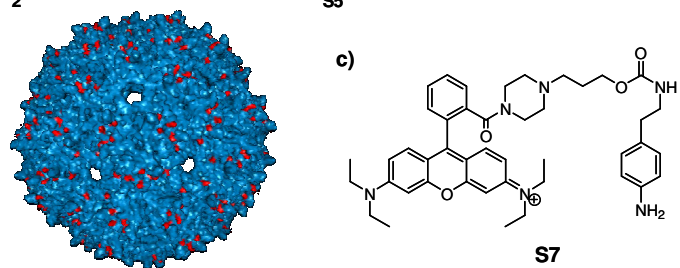

d)

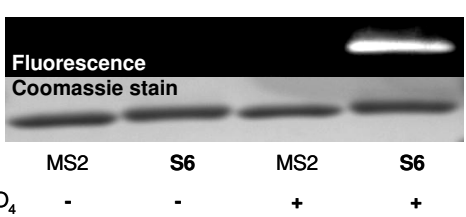

Figure S10. Reaction of aniline bearing dye with $N, N$-diethyl-p-phenylenediamine labeled protein. (a) Conversion of $N, N$ diethyl- $p$-phenylenediamine to an active ester was achieved by a one-pot two step method. The resulting NHS-ester was used to label lysines of the bacteriophage MS2. Upon incubation of the labeled protein with an aniline bearing fluorescent dye in the presence of $\mathrm{NaIO}_{4}$, protein-dye coupling was observed. (b) Crystal structure rendering of the MS2 coat protein shell with reactive lysine residues highlighted in red. (c) Aniline bearing fluorescent dye structure. (d) SDS-PAGE analysis of MS2 labeling reactions. Bioconjugation is only observed in the case where all three necessary components (aniline dye, diethylphenylene diamine labeled protein, and oxidant) are present.

\section{Proposed Mechanisms}

a) Diiminoquinone Based Mechanism<smiles>[R]C(=O)Nc1ccc(N(CC)CC)cc1</smiles><smiles></smiles><smiles>[R]C(=O)N=C1C=CC(N(CC)CC)=CC1(NCC)Nc1ccc([R])cc1</smiles>

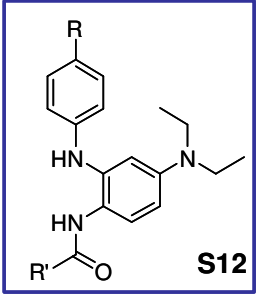

b) Aniline Oxidation Mechanism<smiles>[R]c1ccc(N)cc1</smiles>

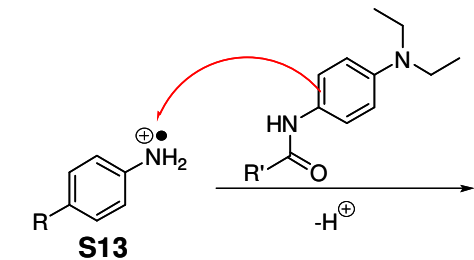

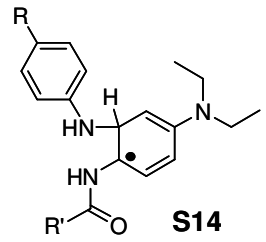
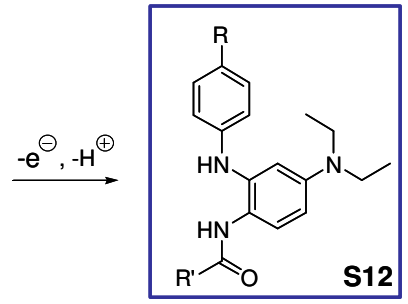

c) Final Product Formation
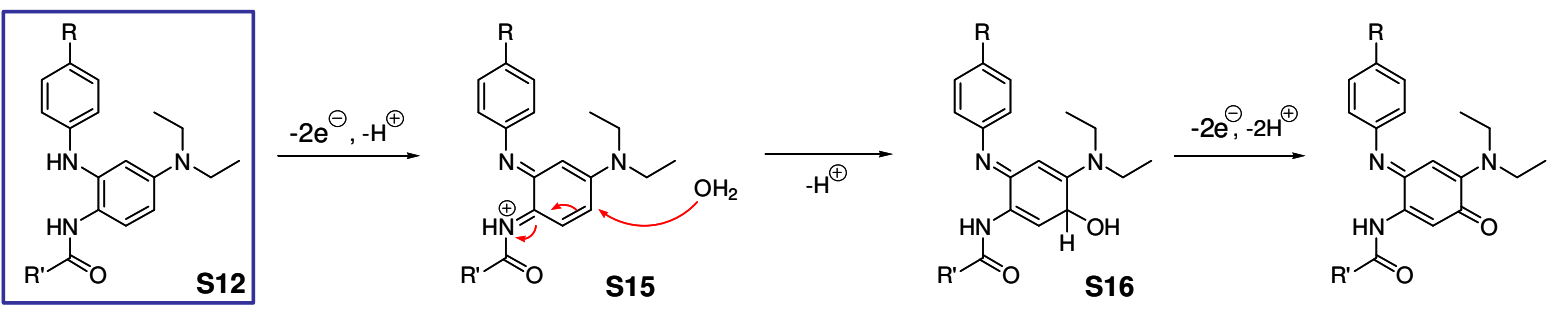

Figure S11. Proposed mechanisms. Only one tautomeric/resonance structure is represented for each intermediate although many could be proposed. (a) A two-electron oxidation of the phenylene diamine derivative results in a diiminoquinone, S10. Conjugate addition of the aniline nitrogen followed by tautomerization leads to intermediate S12. (b) Single electron oxidation of the aniline moiety leads to a radical cation, S13. Subsequent radical coupling with the electron rich phenylene diamine is followed by oxidation resulting in intermediate $\mathbf{S 1 2}$. (c) Final product formation results from a series of oxidations coupled with an addition of water. This is represented through two-electron oxidations. 


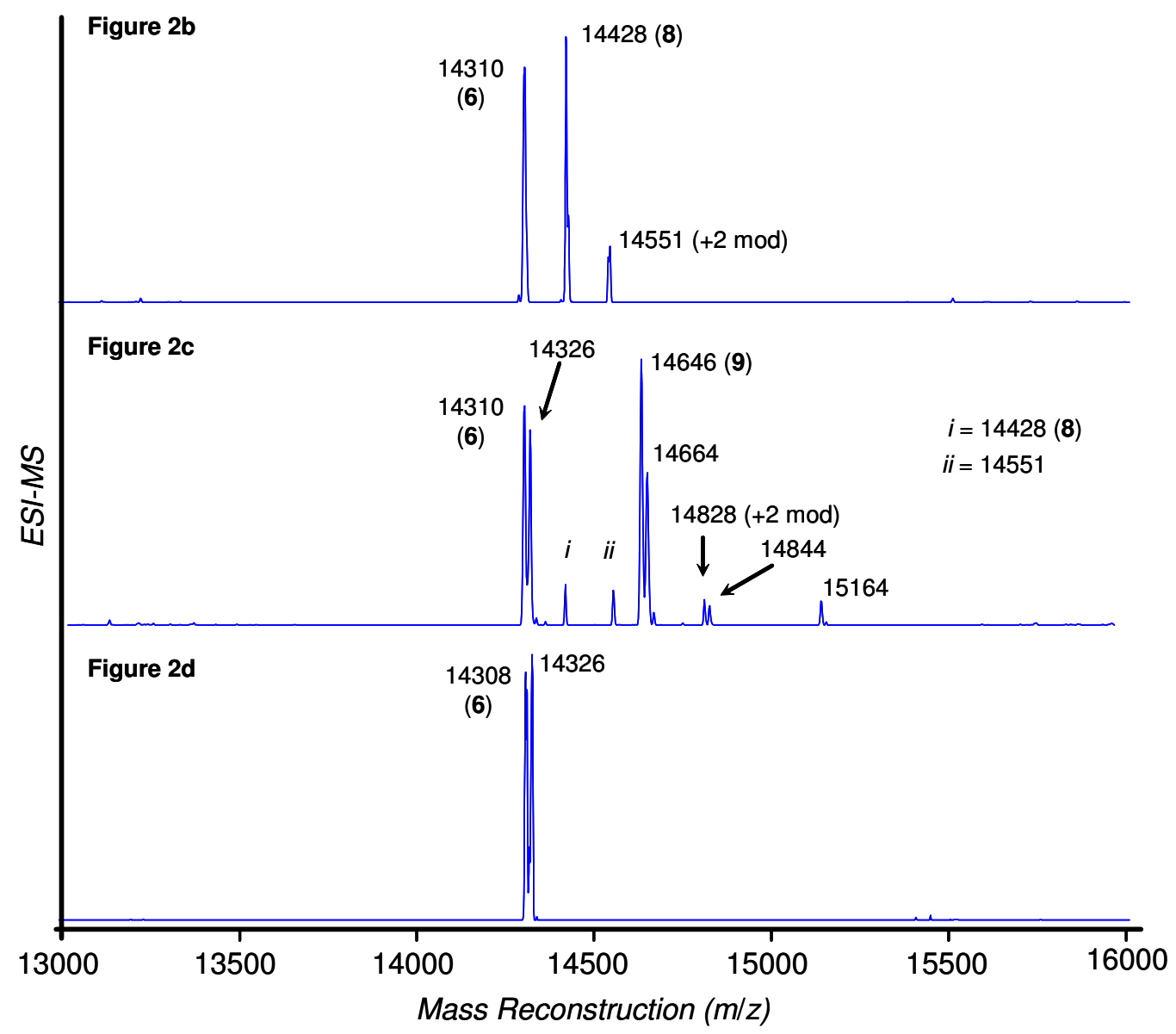

Figure S12. Large scale mass spectra from Figure 2. Electrospray LC/MS analyses were performed using an API 150EX system (Applied Biosystems, USA) equipped with a Turbospray source and an Agilent 1100 series LC pump. Spectra were collected in positive ion mode. Protein chromatography was performed using a Phenomenex Jupiter C5 reversed phase column $(2.0 \mathrm{~mm} \times 150 \mathrm{~mm})$ with a MeCN:ddH2O gradient mobile phase containing $0.1 \%$ formic acid $(250$ $\mu \mathrm{L} / \mathrm{min}$ ). Protein mass reconstruction was performed on the charge ladder with Analyst software (version 1.3.1, Applied Biosystems).

\footnotetext{
${ }^{1}$ Nguyen, T.; Francis, M. B. Org. Lett. 2003, 5(18), 3245-3248.
} 